\title{
Comparison of Elastic and Corrosion Behaviour of Sintered Iron Before and After Its Long Time Immersion in Hank's Solution
}

\author{
Miriam Kupkovál, ${ }^{1, *}$,Martin Kupka ${ }^{2}$, Monika Hrubovčákovál \\ ${ }^{1}$ Institute of Materials Research, Slovak Academy of Sciences, Watsonova 47, SK-040 01 Košice, \\ Slovak Republic \\ ${ }^{2}$ Institute of Experimental Physics, Slovak Academy of Sciences, Watsonova 47, SK-040 01 Košice, \\ Slovak Republic \\ *E-mail: $\underline{\text { mkupkova@imr.saske.sk }}$
}

doi: $10.20964 / 2017.04 .18$

Received: 27 December 2016 / Accepted: 6 February 2017 / Published: 12 March 2017

Test bars were prepared from an iron powder by pressing and sintering. Sintered bars exhibited porosity between 15 and $40 \%$. Because of their shape and volume fraction, the pores were expected to form a continuous inter-connected bar-spanning structure. Effective Young's modulus, determined from the frequency of flexural vibration of each bar, increased with decreasing porosity. When brought into contact with Hank's solution, the bars took up corrosion potentials which increased with decreasing porosity. A possible cause was that the external face of a bar (cathode) and internal pore walls (anode) formed a galvanic couple, and the cathode-to-anode area ratio increased with decreasing porosity. After eight weeks of immersion in Hank's solution, each of bars was found heavier as in assintered state, and the weight gain was proportional to the internal surface of the bar. The effective Young's modulus was higher than that of as-sintered material. The corrosion potential was practically independent on porosity. The most likely cause of such a behaviour was a layer of corrosion products covering nearly uniformly almost entire internal surface of a bar. The corrosion/reaction products increased the mass of a bar, enhanced its stiffness in compression, and altered the character of corrosion.

Keywords: sintered Fe materials, porous electrodes, corrosion, Hank's solution, Young's modulus

\section{FULL TEXT}

(C) 2017 The Authors. Published by ESG (www.electrochemsci.org). This article is an open access article distributed under the terms and conditions of the Creative Commons Attribution license (http://creativecommons.org/licenses/by/4.0/). 